\title{
From Myths to Models: \\ The (Re)Production of World Culture Theory in Comparative Education
}

\author{
IVETA SILOVA AND WILLIAM C. BREHM
}

\begin{abstract}
This article traces the emergence of the world culture theory in comparative education using critical discourse analysis. By chronicling the emergence and expansion of world culture theory over the past four decades, we highlight the (unintended) limitations and exclusive regimes of thought that have resulted. We argue that the theory's telos of a "world culture" neglects the notions of power and agency, and continues to use discourses of modernism and "scientific" methodology to justify conformity as the reigning global "norm." The world culture theory ultimately results in an unwitting legitimization of neoliberal policies and its varied educational projects. Drawing on the micro, meso-, and macro-levels of discourse analysis, we examine how the semantics and content of the world culture theory have evolved as it embraced an increasingly large and diverse community of scholars aligned with it. By highlighting some significant semantic shifts during the last four decades, we explore how the world culture theorists forged a relatively new (privileged) space in comparative education-a space that has increasingly turned deterministic and normative. Through a careful deconstruction of some of the basic assumptions of world culture theory, we call for reopening of an intellectual space for new ways of thinking about educational phenomena in the context of globalization.
\end{abstract}


Comparative education has benefited from a multiplicity of perspectives seeking to explain the impact of globalization on education. Yet, some theoretical approaches seem to have assumed more central positions than others. This article focuses on one such theoretical perspective- world culture theory - which explains global convergence as resulting from an ongoing diffusion of "world culture" that creates global scripts for national development (Meyer et al., 1997). Stemming from sociological neo-institutionalism, ${ }^{1}$ world culture theory offers an alternative understanding of the global compared to (macro)realism by emphasizing the role of myths and symbols as key features of globalization processes. According to Meyer and Rowan (1977), myths are widely shared, taken-for-granted cultural ideals - such as rationality, modernity, progress, and justicethat provide a "rational theory" (or scripts) for how organizations, institutions, and individuals should operate $^{2}$ (p. 342). From the world culture perspective, these myths are believed to be legitimate, playing "a central role in shaping a general narrative that informs models of the good nation-state and the good citizen":

Central to this narrative is the role of education as a means to progress and justice. Education is in fact the most legitimated and most scripted means to attain these goals. All sorts of educational and related principles, policies, and practices make sense given the triumph of a world educational culture. All sorts of expertise are aligned to this culture, both gaining legitimacy from it and strengthening it at the same time. (Ramirez, 2012, pp. 430-431)

Initially aiming to explain the expansion of mass schooling after World War II, world culture theory has evolved to examine global trends in education and other fields. In fact, Ramirez (2012) argues that identification of worldwide trends is now "a staple of world society research" (p. 434). From the world culture perspective, these trends seem to be exclusively patterned on Western (predominantly North American) logics, suggesting that there is "a world-cultural preference for market systems and political democracy" (Meyer et al., 1997, p. 167). Research along these lines primarily focuses on the diffusion of progressive policies, whereas world culture effects in other policy domains (e.g., neoliberal reforms) receive less scrutiny (Beckfield, 2003). The underlying assumption is that integration of nation-states into the (Western) world culture prompts policy

\footnotetext{
${ }^{1}$ There have been many phrases coined in the literature to describe the world culture theory. It has roots in sociological institutionalism (a term used to distinguish it from other disciplines such as political science, which occasionally use institutional analyses) which focuses on the importance of rule structures in human behavior. Sociologists such as John Meyer noticed an acute break with previous branches of institutionalism and began classifying the theory "neoinstitutionalism" to emphasize the break with the "old" institutionalists. Since the notion of a world society arises in much of neo-institutional literature, the term used to describe this thinking became "world culture theory," and the debate in comparative education has thus been dubbed the "world culture debate." We will use the terms world culture theory/theorists/debate in this paper as well as "world polity" when used in the title of a work under examination. See Wieseman, Astiz, and Baker (2013) for a discussion on the diveristy of thinking within neo-institutuional theory and the place of world culture theory in the literature .

2 According to world culture theory, actors are also scripted. Their role is to enact rationalized myths. Using the analogy of a John Wayne movie, Meyer (2009) describes the difference between realists' and world culture theorists' understanding of actorhood in the following way: in the realist perspective, what is seen on the screen is believed to be the "real" John Wayne, no questions asked. In world culture theory, by contrast, one realizes that what appears on the screen is "a very ordinary actor (perhaps even a wimp) playing the part of John Wayne - a part written by a screenwriter who isn't an actor at all, and may not know how many legs a horse has" (p. 42).
} 
adoption in such diverse domains as educational expansion, environmental protection, gender equality, human rights, and economic liberalization across different societies worldwide. Viewing world culture as increasingly universal and nonhierarchical in nature (Beckfield, 2010), world culture scholarship infers that structural inequality will gradually decline worldwide.

While sparking much research on policy convergence, world culture theory remains quite controversial in both sociology and comparative education literature (Beckfield, 2010). One of the most enduring criticisms points to the failure of world culture theory to explain the commonly observed disconnect between policy and practice, that is the question of "decoupling" or "loosecoupling" (Meyer \& Rowan, 1977; Meyer et al., 1997, pp. 154-6). On the one hand, for example, education anthropologists used numerous case studies to reveal a disconnect between global norms and local meanings, ultimately questioning the universality of the world culture (see the edited volume by Anderson-Levitt, 2003). On the other hand, critics argued that the diffusion of global policy scripts does not necessarily mean their adoption in local contexts, suggesting they could be merely a "window dressing" that has little or no impact on actual policy outcomes (SteinerKhamsi, 2004; Silova, 2006). Another line of critique points to the neglect of power dynamics in world culture analysis, arguing that such an account denies agency and reflective action within civil society and dismisses real group struggles that effect social change (e.g., see Stromquist's and Griffiths \& Arnove's articles in this journal issue for an elaborate critique). Yet another critique questions ideological foundations, methods, and evidence used in world culture research, suggesting that such research not only fails to support its own claims, but also produces and ultimately legitimizes world culture itself (Carney, Rappleye, \& Silova, 2012).

This article extends the existing critique by carefully interrogating the telos of world culture theory. More specifically, we direct our focus to the genealogy of the world culture theory in comparative education through a discursive analysis of some of the major texts published during the last four decades (1977-2010). In particular, we examine how the research focus, content, and semantics of world culture theory have evolved, as it embraced an increasingly large and diverse community of scholars aligned with world culture theory. We argue that world culture scholarship has become increasingly normative and deterministic in nature, whereby "world culture" is no longer treated as a hypothesis to be tested in order to explain global convergence (as has been argued most recently by Wiseman, Asitz, and Baker [2013]), but rather perceived as a taken-for-granted reality. In this context, world culture scholarship has contributed to celebrating and consolidating perhaps unwittingly - of the very global trends it aims to explain.

\section{De-Constructing World Culture Theory through Critical Discourse Analysis}

Although used rather infrequently in comparative education (Vavrus \& Seghers, 2010), critical discourse analysis can provide useful insights that go unnoticed with more traditional analytical tools. First and foremost, critical discourse analysis is built on the explicit acknowledgement of power relations between scholarship and society. As van Dijk (2001) explained, critical discourse analysts reject the possibility of a "value-free" science and argue that science, and especially academic discourse, are inherently a part and a product of social structure, which is produced in social interaction. "Instead of denying or ignoring such a relation between scholarship and society," critical discourse analysts study power relations in their own right (van Dijk, 2003, p. 352). In other words, critical discourse analysis allows us to recast all research data and findings 
as "discourse" and make researchers' own words a key area for analysis (Luke, 1997). Furthermore, while recognizing that all intellectuals are inherently engaged in "the production of truth," discourse analysis challenges the researcher to go further by examining the "politics of truth":

The essential problem for the intellectual is not to criticize the ideological contents supposedly linked to science, or to ensure that his own scientific practice is accompanied by correct ideology, but that of ascertaining the possibility of constituting a new politics of truth. The problem is not changing people's consciousness — or what's in their heads - but the political, economic, institutional regime of the production of truth. (Foucault, 1980, p. 133)

Second, critical discourse analysis "marks out a new set of methodological techniques and possibilities" (Luke, 1997), including bridging micro-, meso-, and macro-level analyses of text. Following a critical discourse analysis approach developed by Norman Fairclough (1992), we distinguish between three different levels of discourse analysis, while recognizing that these three levels inevitably overlap in multiple and complex ways. The micro-level of analysis (discourse as text) examines linguistic characteristics of texts (e.g., modality, wording, and meanings) and the textual construction of some central concepts in world culture theory such as myth/rationality, individual/society, and others. The meso-level analysis (discourse as discursive practice) examines the intertextual and interdiscursive dimensions of texts to reveal the telos of the theory through the narratives that are present and those that could have been but are absent. Finally, the macro-level analysis (discourse as social practice) looks at the institutional context within which the world culture discourse emerges and becomes legitimized, revealing the philosophical foundations and assumptions. Combined, this three-tiered approach to discourse analysis provides a starting point for understanding the larger questions about the nature of knowledge itself and the intellectual context in which world culture discourse emerges as legitimate.

The data used in our analysis consists of a careful selection of world culture theory texts chosen based on several criteria. First, we examined all world culture publications in Comparative Education Review (CER) published since the 1970s, including a total of 20 publications (three published before the 1970s-1980s and 17 published after the 1990). ${ }^{3}$ Second, we identified "core" world culture theory texts, which have been consistently cited in CER-published articles and that have been referred to as "seminal" publications by world culture theorists themselves, ${ }^{4}$ assuming that these texts have laid the foundations for the development of the world culture theory and its applications in education research. Third, we extended our sample to include publications of the second and third generation of world culture theorists to examine how the theory evolved as a

\footnotetext{
${ }^{3}$ Meyer (1971), Boli, Ramirez, \& Meyer (1985), Fiala \& Gordon-Landford (1987), Benavot (1992, 1996), Meyer, Nagel, \& Snyder (1993), McNeely (1995), Kamens, Meyer, \& Benavot (1996), Frank et al. (2000), Astiz, Wiseman, \& Baker (2002), McEneaney (2003), Suarez (2007a, 2007b), Chabbott (2007), Bromley (2010), Kamens \& McNeely (2010), Moon \& Koo (2011), Frank, Robinson, \& Olesen (2011), Bromley, Meyer, \& Ramirez (2011), Jakobi (2011).

${ }^{4}$ For example, see a list seminal publications identified by Wiseman \& Baker (2006, p. 3). In addition, the following publications were included in the analysis: Meyer (1977), Meyer et al. (1977), Meyer and Rowan (1977), Ramirez and Meyer (1980), Ramirez and Boli (1987), Ramirez (1987), Benavot et al. (1991), Meyer, Ramirez, and Soysal (1992), Meyer et al. (1997), Ramirez and McEneaney (1997), Meyer and Ramirez (2000). In addition, the analysis include the edited volume, World Society: The Writings of John W. Meyer (Krücken \& Drori, 2009), which compiles many of the seminal pieces of world culture theory, particularly those central to its inception.
} 
growing number of scholars utilized it. At this stage, we limited our sample to publications directly focusing on various aspects of educational systems within the world culture theory (such as education policy, assessment, curriculum, governance, gender equality, and others). In this category, we included peer-reviewed articles, book chapters, and books (both authored and edited volumes), which explicitly framed their analyses within world culture theory in comparative education. ${ }^{5}$ It is notable that many of these texts were co-authored by scholars who collectively span three generations of world culture scholars. It is for this reason that we emphasize the overall shift in the literature between the 1980s and 1990s, and not simply over the generations of scholars. Finally, we examined texts directly associated with the world culture debate (such as publications that used the anthropological, sociohistorical, or educational borrowing perspectives) to understand the larger context within which the world culture debate has been rooted. ${ }^{6}$ While these data sources may not provide a complete analysis of all world culture texts, we believe they form a representative sample for us to engage in micro-, meso-, and macro-level discourse analysis of world culture scholarship in the field of comparative education.

\section{Discourse as text: Losing "myths" in a world culture of rationality}

In order to explore the link between discourse and power, it is important to critically examine the textual construction of the assemblage of key concepts used to articulate world culture theory. As Drori and Krücken (2009) noted, world culture theory rests on "several fundamental concepts that are captured in particular terms, which while often shared throughout the social sciences, are given distinct usages for the institutional project" (p. 4). These terms include rationalization, actorhood, diffusion, embeddenness, legitimation, scripts, myth, ritual, and ceremony, among others. These concepts allow world culture theorists to speak "broadly and compellingly about various matters," describing "modern society in a way that articulates trends, points at causal mechanisms, and outlines consequences that are distinctive in the modern social science corpus" (Drori \& Krücken, 2009 , p. 4). A careful analysis of these key concepts is instrumental in understanding how certain words, phrases, and meanings (as seen from the micro-level) collectively work together to create knowledge and ultimately produce social effects.

Given the space constraints of this article, we will limit our discussion to the analysis of one of the core concepts of world culture theory - that of "rationalized myths"-while acknowledging indepth analyses of other core concepts would be equally useful and revealing. The early world culture theorizing is characterized by a clear emphasis on the role of "myths"-whether rationalized, generalized, institutionalized, or legitimating - in defining new domains of rationalized activity and rationalizing the organization's existence. In particular, the world culture publications of the 1970 s and 1980 s saw educational and related policies as rituals that enact "rationalized myths." For example, Meyer and Rowan (1977) devoted an entire section of their article to "the origins of rational institutional myths" (p. 347) and explained in great detail how

\footnotetext{
${ }^{5}$ For example, articles and book chapters include the following publications: Baker (2009, 2011), Bromley (2009), Bromley and Andina (2010), Bromley, Meyer, and Ramirez (2011), Chabbott (2006), Mori and Baker (2010), Ramirez, Bromley, and Russell (2009), Ramirez and Meyer (2002), Ramirez and Wotipka (2001), Suarez and Bromley (2012), Suarez and Ramirez (2007), Wiseman (2007, 2008, 2010), Wotipka and Ramirez (2008). Books and edited volumes included the following publications: Baker and LeTendre (2005), Benavot and Braslavsky (2006), Chabbott (2003), and Wiseman and Baker (2006). We have also included all education-related publications from the "world society-world polity theory bibliography," which was compiled by Boli, Gallo-Cruz, and Mathias (2009).

${ }^{6}$ For example, see Anderson-Levitt (2003), Drori, Meyer, and Hwang (2006), Steiner-Khamsi (2004), and Schriewer (2012).
} 
these myths function "as rational means to the attainment of desirable ends" (p. 345). Similarly, Ramirez and Boli (1987) distinguished between five different "myths" - the individual, the nation as a society made up of individuals, progress, childhood socialization, and the state as guardian of the nation - which are key concepts for our understanding of the process by which mass schooling became institutionalized worldwide (see Table 1).

Although world culture scholarship was heavily criticized for going "overboard with myths and symbols" as early as mid-1980s (see Perrow, 1985), the concept of "rationalized myths" is nevertheless important because it emphasizes both the imagined nature of the world society, as well as the imagined nature of "global norms" and "models." This conceptualization is directly connected to the original world culture theorizing. The use of "myths" gives connotations of fluid, malleable ways actorhood works, even if those "myths" are powerful in society. The individual, the nation as a society made up of individuals, progress, childhood socialization, and the state as guardian of the nation - all of these "myths" are not overtly defined by a menu of educational policies but rather open to interpretation. The idea of "myths" is the conceptualization-in a sense a typology - by which global trends could be described and explained. When Meyer (1977) suggested, "the effects of myths inhere, not in the fact that individuals believe them, but in the fact that they 'know' everyone else does, and thus that for all practical purposes the myths are true" ( $p$. 75), he was not prescribing how these myths translate into real policy but rather was giving researchers a way to understand why individuals act in certain ways.

Yet, "myth" has practically disappeared from neo-institutional publications in the field of education by the early 1990s. While the idea of "rationalized myths" may have remained in world culture theory publications (see Table 1), the word "myth" itself has gradually vanished. For example, the term "myth" did not appear in most publications authored by second and third generation scholars who used world culture theory as their explanatory framework, including approximately 80 percent of world culture theory-based articles published in Comparative Education Review in the last three decades (1990s-2010s). Similarly, the concept of "myth" was mentioned only once (and in passing) in National Differences, Global Similarities: World Culture and the Future of Schooling, a book by Baker and LeTendre (2005), which is used as a key text in many comparative education courses to explicate a world culture approach.

-- Insert Table 1 here [myth table] --

The disappearance of "myth" from world culture theorizing in comparative education may seem inconsequential at first glance. As Fairclough (1989) pointed out, however, "wording" is never an innocent matter. For the world culture debate in comparative education, the loss of "myth" has had very important implications-Meyer's "global imagined community" has increasingly begun to assume very real characteristics. Actorhood has changed from being a socially constructed myth to become modeled, mapped, and molded to particular conceptions of the "good" actor. As "myths" became recast as "models," the malleability of the social construction of actorhood has turned into more rigid conceptualizations. Thus, world culture theory became not a way to understand the global as a series of fluid "myths" (as the theoretical project originally intended), but rather a way to see the global through a particular lens where descriptions and explanations are intimately tied to specific educational solutions. In other words, despite the claim that "neo-institutional perspectives do not advocate for or against 
legitimised expectations, activities or norms in comparative education research" (Wiseman, Asitz, \& Baker, 2013, p. 14), we see a shift from "world culture" being treated as hypothesis to "world culture" becoming a fact and/or finding. This suggests that the interpretation of educational phenomena, no matter which theory is used, is based on the researcher's vantage point and location. Given that world culture theory originated in the West (in what is often labeled "the Stanford school" of thought) and was propelled by a group of predominantly North American-trained scholars, it is not surprising that the content of the world culture theory has assumed a particular subjectivity despite its self-presentation as neutral, "scientific," and impartial.

\section{Discourse as discursive practice: World culture and its neoliberal "reading" of the world}

We can see the way in which world culture theorists read the world in the kinds of "global trends" they individually and collectively-often relying on self-reference-identify as emerging and spreading worldwide. ${ }^{7}$ With the disappearance of "myth" and with the extension of the theory from mass schooling to more specific areas of the educational system (whether curriculum, governance, education policy, or gender equity trends), the "world culture" has begun to assume very specific characteristics. An analysis of world culture theory publications in the area of comparative education over the last two decades (1990s-2010s) reveals a dominant vision of the "world culture" reflecting Western (liberal) ideals, paralleling Drori's (2006) observation of global governance reforms that assumed "transparent nation-states managed by accountable governments and operating in a world of open international markets" (p. 112).

Generally, these trends contain "a package" of progressive civil rights policies and liberal economic policies (Beckfield 2003, 418). In particular, world culture scholars highlight the worldwide dissemination of such "progressive" policies as human rights (Hafner-Burton \& Tsutsui 2005; Suarez 2007a, 2007b), environmentalism (Bromley, Meyer \& Ramirez,, 2011; Frank, Robinson, \& Olesen 2011; Moon \& Koo 2011), and women's suffrage and educational opportunities (Ramirez, Soysal, \& Shanahan 1997; Ramirez \& Wotipka 2001; Wiseman 2008). At the same time, however, world culture theorists also focus on the following set of education "models," which many scholars would commonly identify as central to the coercive spread of neoliberal ideology in education:

- decentralization, devolution, privatization, and marketization of schools (Astiz, Wiseman, \& Baker, 2002; Baker \& LeTendre, 2005)

- standardized curriculum with an emphasis on math and science (Benavot et al., 1991; Benavot \& Braslavsky, 2006; Baker \& LeTendre, 2005)

- national educational assessment and international testing (Kamens \& McNeely, 2007, 2010; Benavot \& Tanner, 2007; Wiseman \& Baker, 2006)

- evidence-based education policy (Wiseman \& Baker, 2006; Wiseman, 2010)

\footnotetext{
${ }^{7}$ In our analysis of the "world society-world polity theory bibliography," which was compiled by Boli, Gallo-Cruz, and Mathias (2009), world culture theorists' reliance on referencing other "Stanford school" scholars was clearly visible. This self-referencing, although not problematic in and of itself, can create a closed system of circular knowledge - the legitmation of a specific view by claiming another scholar has published the same view elsewhere. In other words, a hypothesis that has been tested in earlier research becomes cited as a proven and taken-for-granted reality by the new generation of scholaes without critical engagement with alternative explanations.
} 
- managerialism and rationalization of universities (Krücken \& Meier, 2006)

While making observations about the spread and dominance of certain education reform models is neither problematic in itself nor indicative of implicitly endorsing these models, there seem to be several problematic issues with the explanatory logic of world culture theory in this regard. In particular, world culture scholarship has slid into describing very specific types of education models (predominantly neoliberal), relying on a very specific set of data and methodology (usually referred to as "scientific"), and using a very specific vocabulary to describe their findings (generally presented from a positive - and positivist-perspective). First, world culture scholarship provides a theoretical explanation of the worldwide spread of selectively identified "global norms" (Western in origin and neoliberal in nature), leaving a multitude of innovative education initiatives unnoticed and thus reinforcing the status quo. Second, the language embedded in world culture theorizing itself recasts these neoliberal education policies as the "common good"—as something that is ultimately positive - thus further legitimizing the already powerful position of the neoliberal project in the global education landscape. Finally, the fixation of world culture theorists with scientific methodology and their preoccupation with quantitative data makes world culture theorizing appear as rational, impartial, and non-judgmental with respect to issues of major moral concern, thus masking its normative stance. The sections that follow elaborate on these three points.

World culture with Western features: On geopolitical determinism of world culture theory World culture theory typically describes and sustains (by its lack of criticism) a vision of educational reforms based on neoliberal ideas manifested in the Washington Consensus (i.e., rationalities of the International Monetary Fund, development banks, and multilateral agencies). These reforms are proposed and supported by international organizations' most active members, nation-states from the West, who benefit from these particular policies (Tikly, 2004). ${ }^{8}$ Although some world culture research in education focuses on progressive policy changes (for example, gender equality, human rights), Beckfield (2003) noticed "an intriguing resolution of this paradox might be that world-policy scripts contain a package of neoliberal economic policy and technical harmonization bundled with progressive policy in other domains" (p. 418). By limiting their analytical lens to broad macro-level trends in a field marked by aggressive politics and uneven power relations, the application of world culture theory in education not only lacks complexity, but also becomes seriously superficial. By not critiquing but rather identifying and documenting the diffusion of these Western, neoliberal reform packages in the domain of education - ultimately at the expense of policy alternatives - world culture theory legitimizes the continued dominance and perpetuation of the dominant vision.

Furthermore, one of the underlying assumptions of world culture theory (and one of its critiques) is its overemphasis on global convergence (Finnemore, 1996). This naturally implies a lack of difference or at least a decrease in differences as isomorphic trends progress worldwide. In fact, some world culture theorists believe that difference should be overlooked: "Without a doubt, we can observe cultural differences among German, Japanese, and American classrooms. But we need

\footnotetext{
${ }^{8}$ See Tikly (2004) for a more detailed discussion on how Western development efforts (and the rationalities embedded in them) constitute a form of "new imperialism."
} 
to be careful not to focus too much on these differences, and not to assume that the patterns are stable across time" (Baker \& LeTendre, 2005, p. 113). This intentional focus on dominant models comes at the expense of ignoring "the multiple perspectives and concerns" of those groups and individuals who find themselves on the fringes of globalization- "feminists, indigenous groups and new social movements as they attempt to grapple with the implications of globalization and social change" (Tikly, 2004, p. 178). What is not described-what is negated-in world culture theory then, becomes an important way to reveal its telos, its underlying aim as a theoretical project, which allows it — consciously or otherwise - to normalize neoliberal policies.

The inclination to focus on dominant models while glossing over difference and divergence puts world culture theory in the position of geopolitical determinism, where, in effect, a theoretical perspective is used to advocate for a specific world order (Silova \& Brehm, 2010). The history of the theory's development gives context to this position. The emergence of world culture theory coincided with a stabilization period during the Cold War in the 1970s, opening space for alternative explanations of the global compared to Realpolitik, a politics based primarily on power and material factors. As the socialist bloc collapsed in 1989, the West (particularly the United States) experienced increased power internationally_-both real and rhetorically. This geopolitical move towards political, economic, and ideological hegemony by the US corresponded to world culture theory's semantic shift from "myths" to "models"- the prescriptions of certain institutional blueprints. Although Meyer and colleagues (1997) pointed to the dominance of the US since WWII as "...one explanation for the current world-cultural preference for market systems and political democracy," the dominance was more acutely present during the post-cold war years of unchallenged US hegemony, at least in terms of world culture theoretical models (p. 167, emphasis added). In fact, Ramirez (2012) referred to the fall of the Soviet Union as a "watershed" date in the world culture analysis:

By the mid-1990s, the fall of the Soviet Union had the practical effect of eliminating or diluting more state-centric models of progress. The myth of the individual becomes less attached to the myth of the state as the protector of the nation. Theorization of progress and of justice will more directly center on educational efforts to expose students to visions of human rights bearing citizens in more student centric curricular materials that call for active engagement in environmental education. (p. 437)

With the new geopolitical configurations, world culture theorists were able to claim with confidence, "[from] an institutional perspective, the United States, often a forerunner in global institutional trends, was just ahead of a general world trend in the production of mass schooling and growing gender equality in education" (Baker \& LeTendre, 2005, p. 17; emphasis added). By accepting dominant reform packages while neither subjecting them to sustained critique nor looking for (or seeing) alternative reform efforts, contemporary world culture theory has effectively celebrated and consolidated the very reform trends it aims to understand.

From "myths" to "best practices:" On normative values of world culture theory Not only does the world culture theory exclusively focus its analysis on the spread of Western, neoliberal education policies worldwide, but it increasingly discusses these policies as "the common good." In the words of Baker and LeTendre (2005), for example, "schooling becomes synonymous with the project of forming the good society that gives modern nations a sense of 
meaning" (p. 178). Similarly, Meyer and Ramirez (2000) discussed how nation-states become increasingly attuned to "...world models of progress and justice" (p. 130). The extent to which a nation adopts global "norms," based on neoliberalism, has become the measure of its world cultureness and success. The countries where fewer "global models" have been implemented, represent the "developing," un-modern parts of the globe. The underlying assumption is that the acceptance of global "models" and "norms" will eventually lead developing nation-states towards modernity, an "effective and tranquil society":

Waves of reform and revival emanating from the movement circulate doctrines of human rights and empowerment, principles of the natural environment, and rationalized models of action and coordination. These doctrines, principles, and models, it is understood, can integrate people and nature in effective and tranquil society - and increasingly on a global scale. Thus we observe their spread and penetration into various social spheres around the world. (Meyer, Drori \& Hwang, 2006a, p. 263, emphasis added)

The normative undertones of world culture theory have intensified as some scholars made a leap from observing and describing the world culture phenomenon to prescribing and endorsing some of the world culture "myths"-now "models" of privatization, standardization, rationalization, and so forth - through their research and publications. As the theory evolved from "myth" to "model," some world culture theorists engaged in articulating prescriptions on how to succeed within this apparent world culture. It is precisely here where the use of certain words help create particular points of view, infusing world culture with normative tendencies. For example, Baker and LeTendre (2005) discussed the emergence of private tutoring (or shadow education) as a new "world megatrend" (p. 55), which "loosens the boundaries between public control of education and private educational activities" (pp. 69-70). While many critics are weary of "hidden privatization" of public education (e.g., Ball, 2007; Ball \& Youdell, 2008; Burch, 2009; Silova, Budiene \& Bray, 2006), world culture theory sees private tutoring as an example of "innovative educational services" (Baker \& LeTendre, 2005, p. 6). In particular, Baker and LeTendre (2005) explained:

...widespread shadow education adds a significant nonpublic component to national school systems without the production of full-scale private schooling. This has the potential to change the governance structure of education by introducing private services to a wider host of families and students, hence merging families, mass schooling, and private educational resources into new institutional arrangements unheard of just a few decades ago. (p. 70)

Despite some purposeful attempts to appear non-judgmental in their analyses, ${ }^{9}$ similar examples of normative argumentation permeate much of the world culture literature. Whether focused on

\footnotetext{
${ }^{9}$ One example of claiming value-neutrality is the frequent use of the phrase "for better or worse" when describing "global norms" and "models." This phrase is used commonly in the world culture literature across different generations of scholars. For example, "science is socialized, for better or worse, but society itself is scientized" (Drori \& Meyer, 2006, p. 53; emphasis added). And, "although there may be certain elements of each nation, region, or culture that will influence local level schooling there is, for better or worse, a trend of isomorphism in educational policy and practice." (Wiseman \& Baker, 2006, p. 7; emphasis added). A more fully articulated explanation could be found in an article by Chabbott (2007) who clarified that "the emphasis...on Western science throughout much of this article
} 
accountability trends in higher education, evidence-based education policymaking, or standardized curriculum, world culture theory consistently recasts these "world models" as effective, efficient, and equitable. As Dale (2000) observed, these examples indicate world culture is "politically rather than cognitively propelled" (p. 447). This political orientation becomes more obvious as some world culture theorists enter into discussions of "best practices," arguing, for example, "...there are correct ways to bring about health, schooling, economic development, and democratic politics and the principles of bringing those things about apply everywhere..." (Meyer, Drori \& Hwang, 2006b, p. 37; emphasis added). Importantly, this same critique was forcefully articulated in 1985 by Charles Perrow who warned that world culture theory could be "the unwitting carrier of a conservative laissez faire analysis that ignores basic inequalities in our society" (Perrow, 1985, p. 268).

Given that world culture research in comparative education is increasingly based on data from international assessment studies such as TIMSS (Trends in International Mathematics and Science Study) and PISA (Program for International Student Assessment; see Wiseman \& Baker, 2006, p. 15), the narratives of "best practices" become commonplace. Furthermore, when conformity becomes the reigning norm, the process is set in place to streamline and rank in accordance with that norm. Those who deviate must be brought into line; they must be disciplined - as "the name, shame, and blame" strategy of the TIMSS and PISA studies exemplifies. This normalizing discourse of global trends - justified through global data sets where global problems require global prescriptions (see Hwang, 2006) - is supported by world culture theorists who hold the power of interpretation. Meyer et al. (1997) labeled these professors and statisticians as "rationalized others" who generate "rivers of universalistic scientific and professional discourse" (p. 162). With world culture theory's fixation on scientific methodology, the "rationalized others" who have the knowledge (and power) to interpret large data sets bring with them a "promise of the redemptive powers of human interference" (Ramaekers, 2006, p. 249).

In other words, world culture theory creates a need for rationalized others and a vision for a specifically defined world - a world governed by standardization, rationalization, scientization, and uniformity; a world displaying "astonishing levels of sameness, and a considerable tendency to conformity" (Meyer, Drori \& Hwang, 2006b, p. 49); a world where individuality is demystified "by highlighting its standardization" and where escape from rationality is no longer possible (Drori \& Krucken, 2009, p. 23). It is at this conceptual juncture where world culture theorizing intersects (quite unexpectedly) with the ideas of Foucault, yet draw very different conclusions. The picture of the modern society that both theories paint is strikingly similar. The difference is, however, that Foucault sees power unevenly distributed, whereas world culture theorists believe "authority is diffuse and order emerges from theorized relations among formally equal and thus comparable social entities" (Drori \& Krücken, 2009, p. 24). And while recognizing "the balances between the standardizing and totalizing forces of globalized organization... are almost always unclear, difficult to assess, and are matters of normative contention," world culture theorists take a clear normative position by arguing "the modern globalized world most clearly does not produce a Leviathan" (Meyer, Drori \& Hwang, 2006a, p. 268; emphases added).

indicated recognition of, rather than an uncritical endorsement of, its peculiar authority in international development discourse" (p. 73). 


\section{"In science we trust:" On the role of intellectuals}

An analysis of world culture theory and its main narratives would be incomplete without a discussion of the role of "science" and "scientific" methodology. This is important for two reasons. First, "science" emerges as one of the core narratives in world culture theory, with scientific investigation often described as "the core process in the hyper-organization of world society" (Drori \& Meyer, 2006, p. 53). Second, world culture theory itself heavily relies on "scientific," quantitative data, which gives it legitimacy as a sophisticated, evidence-based, and unbiased theory in the world of social science and education policy making. This symbiotic relationship between "science" and world culture theory - that is, theorizing about the role of "science" in the expansion of the world culture and relying on "science" to theorize about the world culture-produces a diffusion effect of amplifying magnitude. Drori's (2006) description of this diffusion process in the area of governance seems to fit perfectly with the case of world culture theory itself:

...ideas and carriers are the yin and yang of an institutionalization and diffusion process: the institutionalization of ideas reifies the legitimacy of its carriers, while the carriers labor to reproduce, promote, and diffuse the ideas and thus establish their legitimacy...carriers encourage, support, transport, and transform ideas while raising them into the social conscience. (p. 101)

It is not surprising, therefore, that "science" has become one of the core concepts of world culture theory. Drori and Meyer (2006) began their discussion of the role of "science" in globalization with the subtitle "in science we trust" (p. 50) to highlight how "science-based logics and practices have permeated almost all aspects of social life" (p. 50) and "other social institutions: democratization, standardization, environmentalism, and developmentalism" (p. 53). They highlighted how scientized scripts "are used as standards for problem-solving," wherein "science" has the authority not only to define problems but also provide solutions (Drori \& Meyer, 2006, p. 57). Furthermore, world culture theory sees scientization of society as providing "tools for standardized strategies and methods" in order to carry "the mission of rationalization" and deal with "inchoate uncertainties" (pp. 56-57). In the words of Drori and Meyer (2006):

...Science challenges cultural conventions of disarray or mystery by carefully categorizing species, analyzing patterns, modeling behaviours, and deriving laws. From Darwin's analysis of species and their evolution, to Durkheim's analysis of suicide rates and their cultural distribution, to Newtonian laws of gravitational motion-all such scientific breakthroughs seek regularity in the world, social and natural. In these ways, scientific work has cosmological qualities: it reflects the vision of the world order and one's place in it, and this transcends the mundane truths of its discoveries per se. It turns inchoate uncertainties into rationalized and scripted ones. A fatalistic world of opaque terrors becomes comprehensible as a 'risk society'... and thus as something humans can and should organize to deal with. (p. 57)

What is important is that world culture theory projects the image of "science" and "scientization" of society as apolitical, useful, and meaningful. For example, Drori and Meyer (2006) explicitly stated, "scientists and science institutions are not the bearers of social power, as power is ordinarily conceived, but are rather increasingly dependent on society for funding and legitimacy" (p. 55). Furthermore, they present "science" as a "tool of empowerment, instilling and legitimizing the 
agency of social categories seen as passive" (p. 59). In particular, scientization is said to produce modern actors who are to be "something of a scientist," redirecting the locus of action and responsibility to individuals (p. 67). In other words, world culture theory explains the usefulness of scientization in forming "both the expectation of an ordered environment and of rational action, as well as the empowered social actors to lead such action" (p. 66). What is absent from their discussion of scientization of society is the possibility of the manipulation of scientized truths for coercive purposes (for example, see Aronowitz, 1988) or recognition of the stifling effects of governmentality (Foucault, 1991).

Not only does world culture theory reify and narrowly define "science," but it also depends heavily on it for its own research orientation and theorizing project. This philosophy of educational "science" requires hypothesis testing (falsification) and generalizations connecting variables. Educational "science" often uses statistical tools or coding of quantitative data (increasingly drawing on data sets produced by cross-national student achievement studies such as TIMSS and PISA). Not only do these tools look technical and complex and complete, but they also position world culture theorists as "impartial spectators" who are able to avoid value bias by detaching themselves from the normative conceptions of education that shape educational practice (Elliott, 2006, p. 169). Such a reliance on quantitative methodology seems "to promise knowledge stripped of rhetoric and bias" (MacLure, 2006, p. 5), thus giving world culture theory a form of legitimacy beyond political bias. This legitimacy has enabled world culture theory to establish itself in the field of sociology (and the social sciences more broadly) and has helped it establish a firm space in comparative education in the United States, a field that has been preoccupied with the idea of "scientific" (often positivist) techniques and quantitative methodologies since the establishment of the Comparative Education Society (CES) in 1956 (Silova \& Brehm, 2009).

The most unfortunate outcome of the reliance on and the reification of scientific rationality is the attempt to be non-judgmental — value neutral — with respect to issues of major moral concern. The concern is that this new "status quo" could ironically morph into a dystopia, removing agency and action from teachers, students, and administrators. Instead of acknowledging the multiple, often contradictory projects of sense making in late modernity, world culture incapacitates agency by putting it on a path-dependent route towards a narrowly prescribed "world culture."

\section{Discourse as Social Practice: Toward a Conclusion}

The culmination of critical discourse analysis is a "social practice" dimension that brings together insights from micro- and meso-levels into a broader conversation about the nature of knowledge/power relations. Since academic texts are neither value-free nor apolitical (as we have attempted to illustrate in this paper), they assume a power of their own over the public, whether in academic or education policy realms. In the case of world culture theory, this particular knowledge/power relationship is manifest when a theory is transformed (as depicted through four decades of academic scholarship) from a tool to understand the global expansion of mass schooling to a theoretical framework offering a very particular "reading" of the world, one that is neoliberal in nature and assumes a universal adherence of nation-states to the principles of market economies and democratic polities. With the disappearance of "myth" and the extension from mass schooling to more specific areas of the educational system (whether curriculum, governance, education policy, or gender equity trends), world culture theory appears to have resorted to legitimizing- 
not mythologizing - the neoliberal project in education; it has done this through the use of correct methods to explain desired educational developments. In this context, world culture theory scholarship became a "proprietary process" with its "research intended to clarify education functions to mystify power and authority" (Samoff, 2007, pp. 71-72).

One (unintended) outcome of this new power/knowledge arrangement is that world culture theory has submitted itself to justifying the status quo in a world dominated by inequality and injustice. Though not necessarily arguing for the status quo in all instances, world culture theory remains content with "explaining" it, thus incapacitating any attempt to question the established power relations by theorizing the non-existence, if not futility of agency. As a result, tangible practices of oppression continue to occupy unchallenged space in educational systems because certain scholars are able to predict, with the dispassionate authority of rational science, that these will evaporate over time in relation to that country's convergence towards the global norms of justice and equity. But how many of those who actually feel the oppression of schooling submit to the notions of world culture theory? And why does this theory resonates more widely in some geopolitical locations (especially the United States) while being received with ambivalence or indifference among intellectual communities elsewhere (for example, the former socialist bloc or China)? The challenge for us, as educational comparativists, is to recognize that we do not stand outside the reconfiguration of contemporary social spaces, educational or otherwise. There is no "outside." Rather we are central to knowledge production processes, which, through the construction of power relations, have very real impacts on how we think and theorize about the world.

Furthermore, since the tenets of world culture theory are all-encompassing, especially with the catch-all term "loose coupling," it assumes features of a grand theory. Recent attempts to extend world culture theory to classrooms, pedagogical practices, and teachers (Baker \& LeTendre, 2005) are probably far from the final extension of the theory. One can surmise that a grand theory which purports to explain everything in time and space will continue to push against the boundaries it confronts - geographic, historical, or otherwise. As Dale (2000) succinctly remarked, "this could leave us asking whether a concept that can apparently explain everything can explain anything" (p. 440).

What is at stake here is comparative education's capacity to retain the will for reflexifity, critical inquiry, and historical sensibility. It is with this perspective - this doubt in a neutrality of our work as intellectuals - where we need to critically engage in one of the most central debates in our field. We need to become "wide awake" to new possibilities by constantly searching, questioning, and reflecting on ourselves and the world we live in (Greene, 1978). We also need to become "wide awake" to the multiplicity of ways to theorize the global and its intersections with education. But this waking up to a new awareness requires a re-opening of intellectual spaces to a wide range of diverse voices that will collectively contribute to new ways of thinking about educational phenomena. It also requires protected public spaces where "clarity-seeking and closure-seeking tendencies" are interrupted (MacLure, 2006, p. 6) and where theorizing about uncertainty and unpredictability is encouraged. It is through the creation of these new spaces that academic debates, including the "world culture" debate, will become more inclusive, self-reflective, and critically engaged in comparative education and beyond. 


\section{References}

Aaronowitz, S. (1988). Science as power: Discourse and ideology in modern society. Minneapolis, MN: University of Minnesota Press.

Anderson-Levitt, K.M. (Ed.) (2003). Local meanings, global schooling: Anthropology and world culture theory. New York: Palgrave Macmillan.

Astiz, M. F., A. W. Wiseman, and D. P. Baker. (2002). Slouching towards decentralization: Consequences of globalization for curricular control in national education systems. Comparative Education Review 46(1), 66-88.

Baker, D.P. (2011). The future of the schooled society: The transforming culture of education in post-industrial society. In M. T. Hallinan (Ed.), Frontiers in sociology of education (pp. 11-34). Dordrecht: Springer.

Baker, D.P. (2009). The invisible hand of world education culture. In D. Plank, G. Sykes, and B. Schneider (Eds.), Handbook of education policy research (pp. 958-968). New York: Routledge.

Baker, D.P. and LeTendre, G.K. (2005). National differences, global similarities: World culture and the future of schooling. Stanford: Stanford University Press.

Ball, S. J. (2007). Education plc: Private sector participation in public sector education. London: Routledge.

Ball, S. J. and Youdell, D. (2008). Hidden privatisation in public education [Report]. Brusells: Education International.

Beckfield, J. (2003). Inequality in the world polity: The structure of international organization. American Sociological Review, 68, 401-424.

Beckfield, J. (2010). The social structure of the world polity. American Journal of Sociology, 115(4), 1018-68.

Benavot, A. (1992). Curricular content, educational expansion, and economic growth. Comparative Education Review, 36 , 150-74.

Benavot, A. (1996). Education and political democratization: Cross-national and longitudinal findings. Comparative Education Review, 40(4), 377-403.

Benavot, A. and Braslavsky, C. (Eds.). (2006). School knowledge in comparative and historical perspective: Changing curricula in primary and secondary education. Dordrecht, Netherlands: Springer, and Hong Kong: Comparative Education Research Centre, University of Hong Kong.

Benavot, A., Cha, Y.-K., Kamens, D., Meyer, J. W., Wong, S.-Y. (1991). Knowledge for the masses: World models and national curricula, 1920-1986. American Sociological Review, 56(1), 85-100.

Benavot, A. and Tanner, E. (2007). The growth of national learning assessments in the world, 1995-2006. Background paper for the Education for all global monitoring report 2008: Education for all by 2015: will we make it? Paris: UNESCO.

Boli, J., Gallo-Cruz, S.R and Mathias, M.D. (2009). World society-world polity theory bibliography. [Online]. Available: http://worldpolity.files.wordpress.com/2009/09/worldsociety-polity-bibliography-1-sept-09.pdf

Boli, J., Ramirez, F.O. and Meyer, J.W. (1985). Explaining the origins and expansion of mass education. Comparative Education Review. 29(2), 145-170.

Boli, J. and Thomas, G.M. (1997). World culture in the world polity: A century of international non-governmental organization. American Sociological Review, 62(2), 171-190. 
Bromley, P. (2009). Cosmopolitanism in civic education: Cross-national trends, 1970-2008. Current Issues in Comparative Education 12(1), 33-44.

Bromley, P. (2010). The rationalization of educational development: Scientific activity among nongovernmental organizations. Comparative Education Review, 54(4), 577-601.

Bromley, P., and Andina, M. (2010). Standardizing chaos: A neo-institutional analysis of the INEE minimum standards for education in emergencies, chronic crises and early reconstruction. Compare: A Journal of International and Comparative Education 40(5), 575-588.

Bromley, P., Meyer, J.W. and Ramirez, F.O. (2011). Student Centrism in Social Science Textbooks: 1970-2005. Social Forces 90(2), 1-24.

Bromley, P., Meyer, J. W., and Ramirez. F.O. (2011). The worldwide spread of environmental discourse in social science textbooks: Cross-national patterns and hierarchical linear models. Comparative Education Review, 55(4), 517-45.

Burch, P. (2009). Hidden markets: The new education privatization. New York: Routledge.

Carney, S., \& Rappleye, J., Silova, I. (2012). Between faith and science: World culture theory and comparative education. Comparative Education Review, 56(3), 366-393.

Chabbott, C. (2007). Carrot soup, magic bullets, and scientific research for education and development. Comparative Education Review, 51(1), 71-94.

Dale, R. (2000). Globalization and education: Demonstrating "common world educational culture" or locating "globally structured educational agenda"? Educational Theory, 50(4), 427-448.

Drori, G.S. (2006). Governed by governance: The institutionalization of governance as a prism for organizational change. In G. S. Drori, J.W. Meyer, and H. Hwang (Eds.), Globalization and organization: World society and organizational change (pp. 91-118). Oxford: Oxford University Press.

Drori, G. S., and Krücken, G. (2009). World society: A theory and research program in context. In G. Krücken and G. S. Drori (Eds.), World society: The writings of John W. Meyer (pp. 1-32). Oxford: Oxford University Press.

Drori, G.S. and Meyer, J.W. (2006). Global scientization: An environment for expanded organization. In G.S. Drori, J.W. Meyer, and H. Hwang (Eds.), Globalization and organization: World society and organizational change (pp. 50-68). Oxford: Oxford University Press.

Drori, G.S., Meyer, J. W., and Hwang, H. (Eds.). (2006). Globalization and organization: World society and organizational change. Oxford: Oxford University Press.

Elliott, J. (2006). Educational research as a form of democratic responsibility. Journal of Philosophy of Education, 40(2), 169-185.

Fairclough, N. (1989). Language and power. London: Longman.

Fairclough, N. (1992). Discourse and social change. Cambridge, UK: Polity Press.

Fiala, R. and Gordon-Lanford, A. (1987). Educational ideology and the world educational revolution, 1950-1970. Comparative Education Review 31, 315-32.

Finnemore, M. (1996). Norms, cultures, and world politics: Insights from sociology's institutionalism. International Organization, 47(4), 567-597.

Foucault, M. (1991). Governmentality. In G. Burchell, C. Gordon, and P. Mille (Eds.), The Foucault effect: Studies in governmentality (pp. 87-104). Hemel Hempstead: Harvester Wheatsheaf.

Foucault, M. (1980). The history of sexuality: volume 1. New York: Vintage. 
Frank, D. J., Wong, S.-Y., Meyer, J. W., Ramirez, F.O. (2000). What counts as history: A crossnational and longitudinal study of university curricula. Comparative Education Review, 44(1), 29-53.

Frank, D. J. Robinson, K. L., and Olesen, J. (2011). The global expansion of environmental education in universities. Comparative Education Review, 55(4), 546-573.

Greene, M. (1973). Teacher as stranger. Belmont, CA: Wadsworth Publishing Co., Inc.

Hafner-Burton, E. and Tsutsui. K. (2005). Human rights in a globalizing world: The paradox of empty promises. American Journal of Sociology, 110,1373-1411.

Hall, Peter A. and David Soskice, Eds. 2001. Varieties

Hwang, H. (2006). Planning development: Globalization and the shifting locus of planning. In G.S. Drori, J.W. Meyer, and H. Hwang (Eds.), Globalization and organization: World society and organizational change (pp. 69-90). Oxford: Oxford University Press.

Jakobi, A. (2011). Political Parties and the Institutionalization of Education: A Comparative Analysis of Party. Comparative Education Review, 55(2), pp. 189-209

Kamens, D. H., and McNeely, C.L. (2007). International benchmarking and national curricular reform: Educational goal setting and assessment effects. Paper presented at the Annual Conference of the Comparative and International Education Society, March 13, Baltimore.

Kamens, D. H., and McNeely, C.L. (2010). Globalization and the growth of international educational testing and national assessment. Comparative Education Review, 54(1), 526.

Kamens, D.H., Meyer, J.W., and Benavot, A. (1996). Worldwide patterns in academic secondary education curricula. Comparative Education Review, 40(2), 116-138.

Krücken, G. and Drori, G.S. (Ed.). (2009). World society: The writings of John W. Meyer. New York: Oxford University Press.

Krücken, G. and F. Meier (2006). Turning the university into an organizational actor. In G.S. Drori, J.W. Meyer, and H. Hwang (Eds.), Globalization and organization: World society and organizational change (pp. 241-257). Oxford: Oxford University Press.

Luke, A. (1997). Critical discourse analysis. In L. Saha (Ed.), International encyclopedia of the sociology of education (pp. 50-57). Oxford: Elsevier.

MacLure, M. (2006). A demented form of the familiar': Postmodernism and educational research. Journal of Philosophy of Education, 40(2), 224-239.

McEneaney, E.H. (2003). The worldwide cachet of scientific literacy. Comparative Education Review, 47(2), 217-237.

McNeely, C.L. (1995). Prescribing national education policies: The role of international organizations. Comparative Education Review, 39(4), 483-507.

Meyer, J.W. (1971). Economic and political effects on national educational enrollment patterns. Comparative Education Review, 15(1), 28-43.

Meyer, J. W. (1977). The effects of education as an institution. American Journal of Sociology,83, 55-77.

Meyer, J. W. (2009). Reflections: Institutional theory and world society. In G. Krücken and G. S. Drori (Eds.), World society: The writings of John W. Meyer (pp. 25-49). Oxford: Oxford University Press.

Meyer, J.W., Boli, J., Thomas, G. M., and Ramirez, F. O. (1997). World society and the nationstate. American Journal of Sociology, 103(1), p. 144-81.

Meyer, J.W., Drori, G. S. and Hwang, H. (2006a). Conclusion. In G.S. Drori, J.W. Meyer, and H. 
Hwang (Eds.), Globalization and organization: World society and organizational change (pp. 258-274). Oxford: Oxford University Press.

Meyer, J.W., Drori, G. S., and Hwang, H. (2006b). World society and the proliferation of formal organization. In G.S. Drori, J.W. Meyer, and H. Hwang (Eds.), Globalization and organization: World society and organizational change (pp. 25-49). Oxford: Oxford University Press.

Meyer, J.W., Nagel, J., and Snyder, C.W. (1993). The expansion of mass education in Botswana: Local and world society perspectives. Comparative Education Review, 37(4), 454-475.

Meyer, J.W. and Ramirez, F. O. (2000). The world institutionalization of education. In J. Schriewer (Ed.), Discourse formation in comparative education (pp. 111-132). Berlin: Peter Lang.

Meyer, J., Ramirez, F. O., Rubinson, R., and Boli-Bennett, J. (1977). The world educational revolution, 1950-1970. Sociology of Education, 50, 242-258.

Meyer, J.W., Ramirez, F. O., Soysal, Y. N. (1992). World expansion of mass education. Sociology of Education, 65(2), 128-149.

Meyer, J.W. and Rowan, B. (1977). Institutionalized organizations: Formal structure as myth and ceremony. American Journal of Sociology, 83(2), 340-363.

Moody, J. (2009). Institutionalism and the "citation core" of sociology. [Online]. Availible: http://worldpolity.files.wordpress.com/2009/08/soccoreciteshighlighted.jpg

Moon, R. and Koo, J.W. (2011). Global citizenship and human rights: A longitudinal analysis of social studies and ethics textbooks in the Republic of Korea. Comparative Education Review, 55(4), 574-599.

Mori, I. and Baker, D. P. (2010). The origin of universal shadow education: What the supplemental education phenomenon tells us about the postmodern institution of education. Asia Pacific Education Review, 11(1), 36-48.

Perrow, C. (1985). Review essay: Overboard with myth and symbols. American Journal of Sociology, 91,151-155.

Ramaekers, S. (2006). No harm done: The implications for educational research of the rejection of truth. Journal of Philosophy of Education, 40(2), 241-257.

Ramirez, F.O. (1987). Global changes, world myths, and the demise of cultural gender. In T. Boswell and A. J. Bergesen (Eds.), America's changing role in the world-system (pp. 257-73). New York: Praeger.

Ramirez, F. O. (2012). The world society perspective: Concepts, assumptions, and strategies. Comparative Education, 48(4), 423-439.

Ramirez, F.O., and Boli, J. (1987). The political construction of mass schooling: European origins and worldwide institutionalization. Sociology of Education, 60, 2-17.

Ramirez, F.O., Bromley, P. and Russell, S.G. (2009). The valorization of humanity and diversity. Multicultural Education Review 1(1), 29-54.

Ramirez, F.O. and McEneaney, E. H. (1997). From women's suffrage to reproduction rights? Cross-national considerations. International Journal of Comparative Sociology, 38, 6-24.

Ramirez, F.O., Meyer, J.W. (2002). National curricula: World models and national historical legacies. In M. Caruso and H. Tenorth (Eds.), Internationalisation: Comparing educational systems and semantics (pp. 91-107) Frankfurt: Peter Lang.

Ramirez, F.O., \& Meyer, J.W. (1980). Comparative education. The social construction of the modern world system. Annual Review of Sociology, 6, 369-399.

Ramirez, F. O., Soysal, Y. N., and Shanahan, S. (1997). The changing logic of political citizenship: 
Cross-national acquisition of women's suffrage. American Sociological Review 62(5), 735 45.

Ramirez, F. O. and Wotipka, C. M. (2001). Slowly but surely? The global expansion of women's participation in science and engineering fields of study, 1972-92. Sociology of Education 74(3), 231-251.

Samoff, J. (2007). Institutionalizing international influence. In A. F. Arnove and C. A. Torres (Eds.), Comparative education: The dialectics between the global and the local, $3^{\text {rd }}$ edition (pp. 47-78). Plymouth, UK: Rowman and Littlefield Publishers.

Schriewer, J. (Ed.). (2012). Conceptualising the global/local nexus: Meaning constellations in the world society [special issue]. Comparative Education, 48(4), 411-543.

Silova, I. (2006). From sites of occupation to symbols of multiculturalism: Re-conceptualizing minority education in post-Soviet Latvia. Greenwich, CT: Information Age Publishing.

Silova, I., Budiene, V., and Bray, M. (Eds.). (2006). Education in a hidden marketplace: Monitoring of private tutoring. Budapest, Hungary: Education Support Program of the Open Society Institute.

Silova, I. and Brehm, W. C. (2010). Unveiling masked ideologies: Examining the world culture debate in comparative education. Presented at the $54^{\text {th }}$ Annual Conference of the Comparative and International Education Society in Chicago, IL on March 1-5, 2010.

Silova, I. and Brehm, W. C. (2009). Education and geopolitics in a changing Europe: Forty years of scholarship in European Education. European Education: Issues and Studies, 41(2), 730.

Steiner-Khamsi, G. (Ed.) (2004). The global politics of educational borrowing and lending. New York: Teachers College Press.

Suárez, D. (2007a). Education professionals and the construction of human rights education. Comparative Education Review, 51(1), 48-70.

Suárez, D. (2007b). Human rights and curricular policy in Latin America and the Caribbean. Comparative Education Review 51(3), 329-52.

Suárez, D. and Bromley, P. (2012). Institutionalizing a Global Social Movement: Human Rights as University Knowledge. American Journal of Education 118(3), 253-280.

Suárez, D., and Ramirez, F.O. (2007). Human rights and citizenship: The Emergence of Human Rights Education. In C. A. Torres (Ed.), Critique and utopia: New developments in the sociology of education (pp. 43-64). Lanham: Rowman and Littlefield.

Tikly, L. (2004). Education and the new imperialism. Comparative Education, 40(2), 173-198.

Tyack, D. and Cuban, L. (1995). Tinkering toward utopia: A century of public school reform. Cambridge, MA: Harvard University Press.

van Dijk, T. A. (2001). Critical discourse analysis. In D. Tannen, D. Schiffrin \& H. Hamilton (Eds.), Handbook of discourse analysis. (pp. 352-371). Oxford: Blackwell

Wiseman, A. W. (2007). A world culture of equality? The institutional structure of schools and cross-national gender differences in academic achievement. In M. A. Maslak (Ed.), The structure and agency in women's education (pp. 179-199). Albany, NY: SUNY Press.

Wiseman, A. W. (2008). A Culture of (In)Equality?: a cross-national study of gender parity and gender segregation in national school systems. Research in Comparative and International Education, 3(2), 179-201.

Wiseman, A. W. (2010). The uses of evidence for educational policymaking: Global contexts and international trends. Review of Research in Education, 34, 1-24. 
Wiseman, A.W., Astiz, M.F. and Baker, D.P. (2013). Comparative education research framed by neo-institutional theory: a review of diverse approaches and conflicting assumptions, Compare: A Journal of Comparative and International Education,

Wiseman, A. W. and Baker, D. P. (2006). The symbiotic relationship between empirical comparative research on education and neoinstitutional theory. In D. P. Baker and A. W. Wiseman (Eds.), The impact of comparative education research on institutional theory (pp. 1-26). Oxford: Elsevier. 